\title{
Designing Strategies and Green Business Models in the Coconut Oil Industry
}

\author{
Abidin \\ abidin.abidin@ubd.ac.id \\ Buddhi Dharma University Tangerang, Banten, Indonesia
}

\begin{abstract}
As a tropical country, Indonesia has enormous potential for the development of an industry with raw materials from coconut. One of the products that can be developed from coconut is coconut oil. The purpose of this research is to create a strategy and green business model in the medium coconut oil industry (klentik) by utilizing the waste it produces into a variety of prospective products with added value. Various prospective and value added products can be developed from coir, shell, coconut water, dregs, and blondo which are byproducts or waste from the coconut oil production process. The implementation of green business strategies and models has an impact on the sustainability of the medium-sized coconut oil industry, both in terms of profitability, social and environmental aspects.
\end{abstract}

Keywords: coconut oil, green business model, strategy 


\section{PRELIMINARY}

As a tropical country, Indonesia is a suitable country for growing coconut (Cocos nucifera L). This plant can be found in almost all parts of Indonesia from Sabang to Merauke. Based on data from the Asian and Pacific Coconut Community / APCC (2017), Indonesia is a country that has the second largest coconut plantation in the world. Indonesia has coconut plantations covering an area of nearly 3.5 million hectares with a total production per year of close to 14 million grains or almost equivalent to $3 \mathrm{MT}$ of copra. The largest coconut production comes from three islands, namely Sumatra, Java and Sulawesi (Direktorat Jenderal Perkebunan, 2017).

Coconut is known as the tree of life. This is because there are many products that can be produced from coconuts, from the roots, stems, leaves, to the fruit. One product that is widely known in the community and the production process has been carried out from generation to generation is coconut oil. Coconut oil can be produced both from wet coconut and from dry coconut (copra). However, coconut oil has tough competition with palm oil in the market.

To maintain the sustainability of the coconut oil industry, it is necessary to make systematic and continuous efforts related to its strategy and business model. One of the strategies that can be used by the coconut oil industry is the application of the concept of a green business model. According to FORA in Octavia (2012) that the green business model will encourage production innovation and provide a lower environmental impact. According to Abidin (2018), a green strategy in the coconut industry can be carried out through new product innovation by utilizing the resulting waste into other value added products, so that no more waste is thrown into the environment.

Therefore, in this study, the design of a green business model and strategy in the medium-sized industry of traditional coconut oil from coconut milk called klentik oil. This concept aims to produce a green strategy, namely through the utilization of coconut oil industrial waste into value added products so that the zero waste concept can be applied to the medium industry. The purpose of this research is to create a strategy and green business model in the medium-sized coconut oil industry (klentik) by utilizing the waste it produces into a variety of prospective products with added value. 


\section{RESEARCH METHODS}

In this study, the following research methods were used:

1. Identify each stage of coconut oil production starting from input, process, to output. From this stage, data is generated regarding the stages of the traditional coconut oil production process in general and the by-products or waste produced from each stage.

2. Identifying the products that can be produced from coconut oil intermediate industrial waste. At this stage, several products that can be produced from coconut oil waste will be obtained, complete with price information for each of these products.

3. Calculating added value. One of the indicators that the product from the coconut oil industrial waste can be followed up is an indication of the profit that will be obtained from further processing activities on the waste. For this reason, at this stage an overview of added value will be given in the form of profit opportunities that may be generated from processing the coconut oil industry waste.

4. Formulation of strategies and green business models for the coconut oil medium industry. This stage is the final stage, in which a green business model and strategy is prepared as an effort to create a sustainable medium-sized coconut oil industry. 
The research flow diagram used can be seen in Figure 1 below.

Figure 1: Research Flowchart

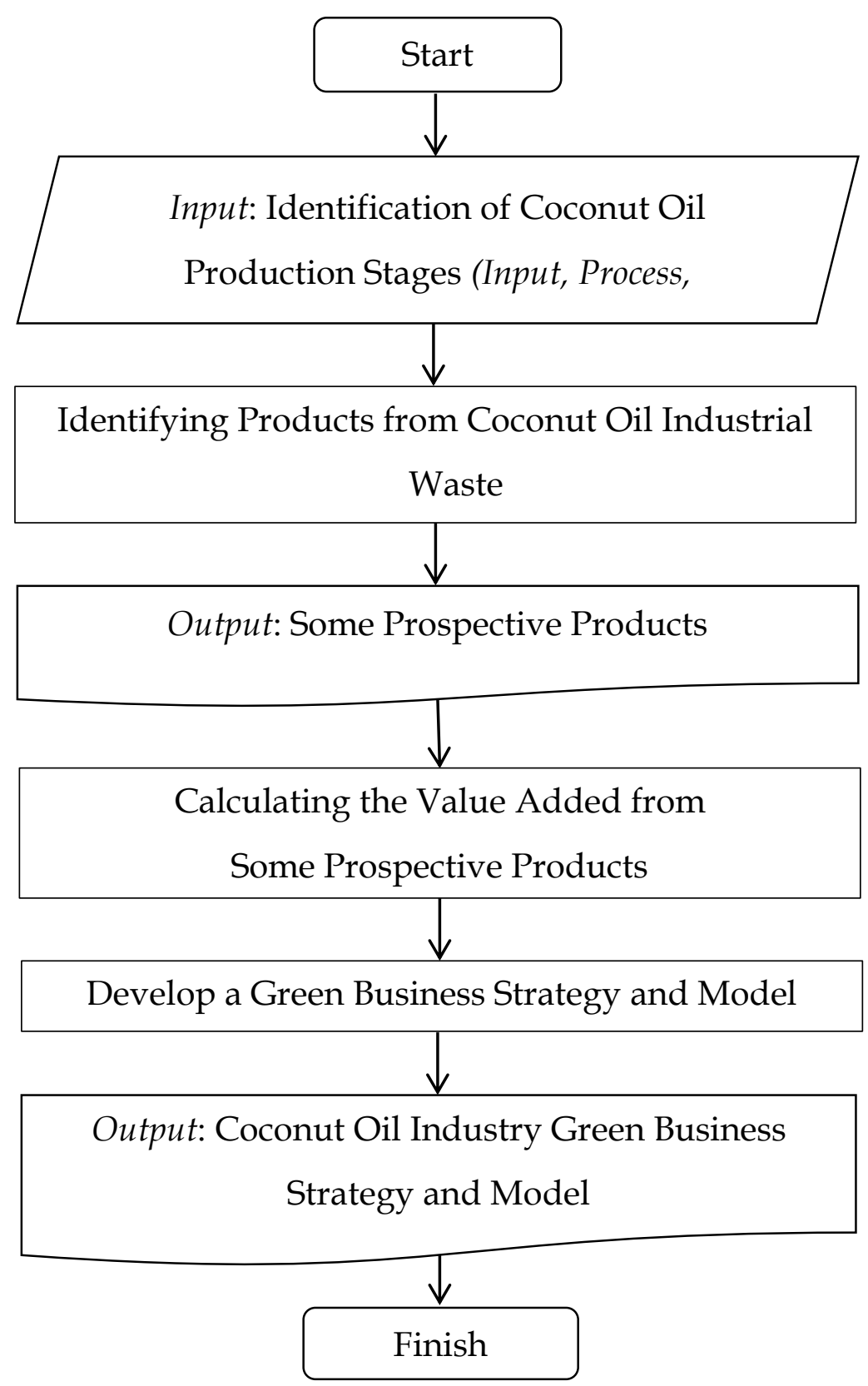

\section{RESULTS AND DISCUSSION}

A. Flowchart Analysis of Coconut Oil Production Process and By-Products

In general, the coconut oil production process (klentik) that is known in the community today can be seen in Figure 2 below. 
Figure 2: Coconut Oil Production Process Flow Chart

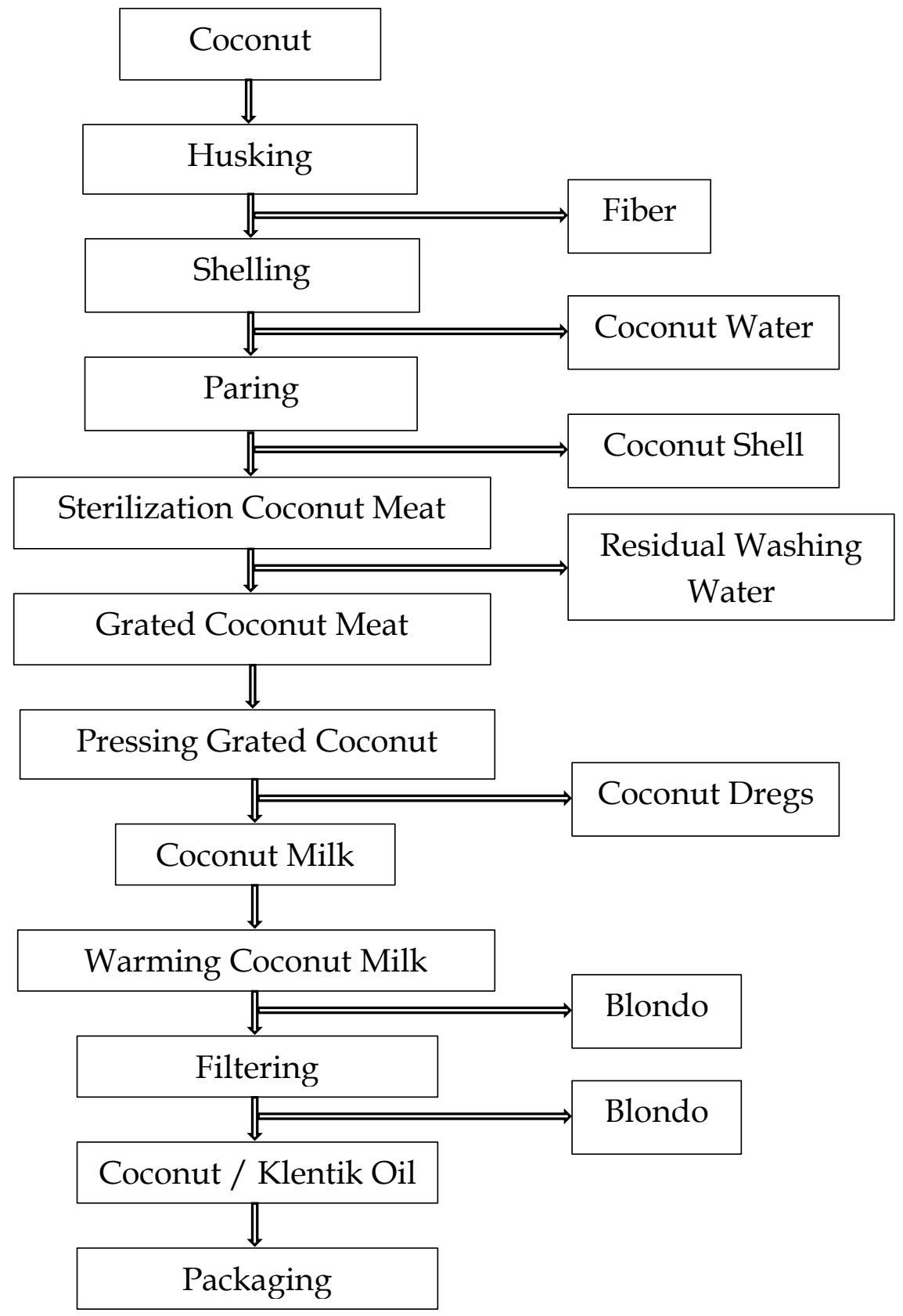

Based on Figure 2, analysis and identification of other prospective products can then be carried out, apart from the main product in the form of klentik oil. The intended prospective product is a product that can be developed from value added waste produced at each stage of the coconut oil production process. The analysis of the production process and other prospective products from the coconut oil medium industry can be explained as follows: 
a. The process of preparing coconut meat.

The coconut fruit is peeled first. From this process, it will produce value added waste, namely coconut husk. Furthermore, to get the coconut flesh, the peeled coconut must be split. This process will produce value added waste, namely coconut water. After it is split, then the coconut flesh is removed from the shell. Therefore, this process produces value added waste, namely coconut shell. The next stage is the coconut flesh which cleans the coconut flesh from dirt sticking from the shell or other sources. This process produces waste in the form of washing residual water. This wastewater must be treated first before the water treatment process is discharged into the environment.

b. Coconut meat processing.

The clean coconut meat is then shredded into small pieces to make it easier to squeeze the coconut milk. To get coconut milk, the grated product is squeezed and from this process it will produce value added waste, namely coconut dregs.

c. Making coconut oil (klentik).

Furthermore, coconut milk is heated to a temperature of $80^{\circ} \mathrm{C}$. From this process, besides producing klentik oil, value added waste is also produced, namely blondo / galendo. After going through the cooling process, the thick oil is then filtered to obtain clean oil. From this process, it will also produce value added waste, namely blondo with a smaller size with a smaller amount than the previous process. After that, the klentik oil is ready to be packaged for market. The selling price of coconut oil (klentik) in the domestic market is around Rp. 10,000/kg - Rp. 15,000/kg (ICC, 2019).

\section{B. Prospective Product Identification and Value Added}

The by-product of coconut oil small industrial waste initially has no commercial value. This is because the by-product is a waste from the production process to produce thick oil. This condition makes the medium-sized coconut oil industry have no additional income apart from sales of klentik oil. Currently, these by-products, especially dry coir and shell, are widely used by the medium-sized coconut oil 
industry as fuel in their production processes. Meanwhile, other by-products tend to become waste and cause problems for the environment.

This condition is certainly not profitable for the coconut oil medium industry and the surrounding environment. Therefore, the by-product, which was originally a waste, needs to be further processed to become a prospective product with added value. Table 1 below is a prospective product that can be produced from coconut oil medium industrial waste along with the selling price in the domestic market.

Table 1: Prospective product from coconut oil medium industrial waste

\begin{tabular}{lll}
\hline \multicolumn{1}{c}{ By-Products / Waste } & \multicolumn{1}{c}{ Prospective Products } & Prospective Product Selling Prices \\
\hline \multirow{2}{*}{ Coconut Fiber } & Cocofibre & Rp. $4.500 / \mathrm{kg}$ \\
& Bulk Cocopeat & Rp. $3.000 / \mathrm{kg}$ \\
Coconut Water & Nata de coco & Rp. $10.000 / \mathrm{kg}$ \\
& Vinegar & Rp. $60.000 / \mathrm{liter}$ \\
& Coconut shell charcoal & Rp. $7.000 / \mathrm{kg}$ \\
Coconut Shell & Coconut activated carbon & Rp. $20.000 / \mathrm{kg}$ \\
& Various creative products & Rp. $5.000 / \mathrm{pcs}-\mathrm{Rp} .250 .000 / \mathrm{m}^{2}$ \\
& & $($ depending on the type of product $)$ \\
Coconut Dregs & Desiccated coconut & Rp. $50.000 / \mathrm{kg}$ \\
Blondo / Galendo & Animal feed / meal & Rp. $8.000 / \mathrm{kg}$ \\
\hline
\end{tabular}

Data source: Abidin (2020)

Based on the data in Table 1, it can be seen that the added value that is owned by the by-product or waste produced by the coconut oil medium industry is very potential for further development. Initially, these wastes do not have a selling price, if any, they are very small. After being processed into various prospective products, the additional income or added value from the waste will contribute to the sustainability of the coconut oil medium industry.

\section{Strategy and Green Business Model of Coconut Oil Industry}

The strategy for developing the medium coconut oil industry is to develop a new business model using raw materials from its production process waste. This new business model is known as the green business model, which is a business model that 
encourages innovation in the use of by-products in the form of waste into prospective, value added products. Thus, in order for the coconut oil medium industry to be sustainable, it is advisable to change into an integrated coconut oil medium industry.

The development of an integrated coconut industry that is calculated using an interest financing system is feasible to be realized (Hendrawati, 2017). Moreover, if you use an interest free financing system approach, it is not only feasible to be realized but will provide better profitability and socio-economic impacts (Abidin, 2020).

According to Daulay (2015), the capacity of the medium coconut oil industry in Indonesia is able to produce $600-700 \mathrm{~kg} /$ day of klentik oil. To produce $1 \mathrm{~kg}$ of klentik oil, 6 coconuts are required. Thus, in one day the raw material for coconut fruit is needed as much as 3,600-4,200 grains/day. Meanwhile, according to Samosir (1991) the composition of each coconut consists of $35 \%$ coir, $12 \%$ shell, $28 \%$ coconut meat, and $25 \%$ water. The average weight per coconut is $2.4 \mathrm{~kg}$ (Sarmidi, 2009). Thus, the potential by-products or waste produced can be seen in Table 2 below.

Table 2: Potential by-product of coconut oil medium industry

\begin{tabular}{lc}
\hline \multicolumn{1}{c}{ By-Products / Waste } & Total Production (kg/day) \\
\hline Coconut Coir & $3.024-3.528$ \\
Coconut Water & $2.160-2.520$ \\
Coconut Shell & $1.037-1.210$ \\
Coconut Dregs & $605-706$ \\
Blondo / Galendo & $2.626-2.947$ \\
\hline
\end{tabular}

If the potential for waste as shown in Table 2 is left unchecked, it will have an impact on the environment in the form of contamination of soil, water and air. By using a green business model and strategy, the potential for environmental pollution from the waste is converted into a potential profit for the company and the application of the concept of zero waste for the environment. With efforts like this, the sustainability of the coconut oil medium industry is more secure. 
Green business strategies and models are expected to complement and strengthen existing strategies, can support operational strategies, such as austerity processes, greener supply in the life cycle chain, and facility efficiency. Green business strategies and models are one of the strategies that can complement business strategies, operations, and include industrial assets that can help decision makers make decisions that have a positive impact on the environment. In addition, a green business model and strategy designed from this concept can become a master plan involving comprehensive actions to promote the development of a sustainable coconut oil medium industry.

The potential for developing a green business model and strategy is also very wide open. This can be seen from the following indicators:

a. The incessant insemination of technology concepts, strategies and green business models through both academic and non-academic channels.

b. There are awards for entrepreneurs or companies that care about the environment.

c. The existence of an environmental management system that applies internationally, namely the ISO 14000 series.

d. There has been a growing awareness of consumers who care about environmentally friendly products.

\section{CONCLUSION AND RECOMENDATION}

Based on the description above, it can be concluded as follows:

a. Various prospective products can be developed from by-products or intermediate industrial waste of coconut oil which can be developed from coir, shell, water, pulp and blondo.

b. The implementation of green business strategies and models has an impact on the sustainability of the medium-sized coconut oil industry, both in terms of profitability, social and environmental aspects.

Furthermore, for further research and development, the following suggestions: 
a. To improve the sustainability of the coconut oil medium industry, it is necessary to build an integrated coconut oil medium industry, which is able to process all parts of the coconut fruit into added value products.

b. Additional studies need to be carried out on various aspects of a feasibility study for the development of an industry.

\section{REFERENCE}

Abidin. 2018. Pemilihan Strategi Hijau (Green Strategy) Pengembangan Agroindustri (Studi Kasus: Agroindustri Kelapa). Jurnal Akselerator. Vol. 3 No. 1, pp: 1-13.

[APCC] Asian and Pacific Coconut Community. 2017. Coconut Statistical Yearbook 2016. Jakarta (ID): Asian and Pacific Coconut Community.

Daulay, S.S. 2015. Pengembangan Minyak Kelapa. Karya Tulis Ilmiah Hasil Survey. http:/ / www.kemenperin.go.id. [24 November 2016].

[Ditjenbun] Direktorat Jenderal Perkebunan Kementerian Pertanian. 2017. Statistik Perkebunan Indonesia 2015 - 2017 Kelapa. Direktorat Jenderal Perkebunan Kementerian Pertanian. Jakarta.

Hendrawati TY. 2017. Kelayakan Industri Kelapa Terpadu. Penerbit Samudra Biru. Yogyakarta.

[ICC] International Coconut Community. 2019. The 50 Years (1969-2019) Cocommunity. Jakarta (ID): International Coconut Community.

Octavia, D. 2012. Analisa Lingkungan Makro, Perilaku Konsumen serta Peluang dan Strategi Bisnis Hijau di Indonesia. Proceeding Seminar: Conference In Business, Accounting and Management (CBAM) 2012. CBAM-FE UNISSULA. Vol. 1 No. 1 Desember 2012, pp: 165-174.

Samosir, Y.M.S. 1991. Asal-Usul dan Botani Kelapa. Di dalam: Makalah Training Budidaya Kelapa untuk Petugas Penyulus Disbun Tk. I Sumatera Utara; Banda Kuala 11 - 20 September 1991. Banda Kuala. Dinas Perkebunan Sumatera Utara.

Sarmidi, A. 2009. Aneka Peluang Bisnis dari Kelapa. Lily Publisher. Yogyakarta.

Dissertation

Abidin, 2020, “Formulasi Strategi Pengembangan Agroindustri Kelapa di Pangandaran Melalui Pembiayaan Partnership Bebas Bunga", Dissertation, IPB University. 